\title{
Human Rights in Sub-Saharan Africa: Towards Complementary Enforcement of Social Justice ${ }^{1}$
}

\author{
By Sufian Hemed Bukurura
}

\section{Introduction}

The past and present decades are said to epitomize the era of good governance and transparency. It is in that context that constitutionalism, human rights and democracy are contemporary subjects of discussion the over. These concepts mean a lot to the organization of societies in general and legal systems in particular. They represent the basis for the very existence of the legal system as well as portraying the images of both the executive and the judiciary. Both the legislature and executive, the very organs which initiate development programmes and which are involved in their implementation, are inclined and bound to violate human rights. It is, therefore, the duty of the least dangerous branch - the judiciary - to keep the two in check, if and when they deviate as expected into excesses and violations of human rights. That wisdom now appears to encompass some doubts. There has been a thinking, the origin of which is not easy to trace, that the judiciary and the legal system in which judiciary is a part, is constituted of conservative minds and inward-looking people. The discussion of complementary human rights enforcement mechanisms and the ensuing debate might go some distance towards the re-examination of that conservatism and its implications to the provision of the necessary checks and balances to existing power relations in general and human rights enforcement in particular. The consequence of the reappraisal of power relations and checks and balances in particular is a challenge not only to lawyers and political scientists, but to all involved and interested in the development of human beings. There is, therefore, a compelling need for finding answers to sour searching questions on whether existing measures against abuse of power and violation of human rights are adequate and effective enough for the enjoyment of the precious inalienable rights and freedoms. With the prevailing inadequacy and ineffectiveness, therefore, there is need to think about other plausible devices so that these rights, which appear to be wished for every citizen and cherished by every one irrespective of world borders could be meaningfully enjoyed with the minimum of restraint.

1

The earlier version of this paper was presented at a Conference on Constitutionalism and Human Rights in a Democracy held at Arusha (Tanzania) in June 1996. The author wishes to express his gratitude to the organisers for their kind invitation. Special thanks to Professor M.H.Y. Kaniki and Mr. Cyriacus Binamungu for reading and commenting on the draft. 
The current economic, political and social set-up of sub-saharan Africa, for example, does not seem to ensure that constitutionalism, human rights and democracy are readily available for the enjoyment of all people. ${ }^{2}$ It can be said, however, that these necessities of present day life are enjoyed only by a few who also happen to be rich, in comparison to other sections of the society. The majority of the citizen seems to be left on the fringes and there is little said or done towards making them available for the majority. The question which arises in that respect is: If the scales of checks and balances have become both unchecked and unbalanced what is it that has to be done to restore the requisite balance? It is beyond the scope of this paper to venture into a reply but only to shed some light on possible directions towards the realization of that goal. Debating this nagging question may be considered part of openness, itself an important aspect of democracy. As it is usually said, knowing the disease is a step towards searching for the cure.

The second part examines how the organ entrusted with redressing the imbalance lost control. In other words, the question to be asked is what are origins of judicial powerlessness? Part three outlines some of the reforms which have been attempted by two countries in which imbalance have been noticed. The last part of the paper makes suggestions for research so that problems that have been brought to light can systematically be thought out and ultimately worked upon in the bid to identify and construct meaningful complimentary measures and reforms.

It needs to be emphasized that human rights are not limited to the civil and political rights, but include the other categories of human rights (social, economic, cultural, the right to development and the right to democratic governance) $)^{3}$ and hence the choice of a broad concept of social justice. This must be so, because the other three generations of tights also need to be emphasized in the same way and probably more than their close kin, the civil and political rights.

\section{Recognition of Judicial Powerlessness}

Liberal democratic practices recognize the judiciary as the custodian of justice in general and the protector of civil and political rights in particular. This appreciation notwithstanding, some general faults have been observed which reveal that the judiciary is neither able nor necessarily best placed to redress all human rights intrusions. For the purposes of this paper it might be said that some weaknesses have been partly attributed to the colonial

Nherere, P. / M. d'Engelbronner-Kolff (ed.), The Institutionalisation of Human Rights in Southem Africa, Copenhagen, 1993.

Franck, T.M., The Emerging Right to Democratic Governance, American Journal of International Law, 86 (1992), pp. 49-91. 
legacy and the historical circumstances of the countries in which common law and RomanDutch systems were imposed. ${ }^{4}$ The inheritance of the legal and political systems provide a background within which the education system, working practices of the politicians and government bureaucrats, including the judiciary, operate. ${ }^{5}$ Some of the weaknesses, however, transcend the history of one particular country and appear to be relatively generalized. That is to say that certain problems related to the effectiveness of human rights enforcement affects rich countries as much as they are observed in poor ones. The USA and Britain, for example, despite their economic muscle, also have records of poor human rights protection and enforcement. The contention here is that it is not necessarily a question of lack of resources that certain violations of human rights pass without being redressed. Of course, lack of resources aggravates the problem in poor Third World countries in general and subsaharan countries in particular, but lack of resources should not be regarded as the only cause to the problem.

Writing in the 1970s, Nwabueze ${ }^{6}$ identified some forms of powerlessness within the judiciaries of Commonwealth Africa in their bid to enforce human rights. Some of these weaknesses appear to have persisted and intensified into the 1990s and probably beyond. Available literature suggests that judiciaries of countries of diverse political persuasions are afflicted with problems like: crises of confidence among the general public, lack of efficiency and effectiveness in their working practices in general and delays and costs of litigation in particular. In some respects opportunism and discipline (or lack of it) have also been mentioned as part of the problem. To totality of these problems is that the judiciary is no longer seen to be the fountain of justice and an effective means of redressing excess of power in general and human rights infringements in particular. In order to understand why this state of affair has come about one needs to look at its causes.

Ncube $^{7}$ has identified two causes relevant here. The executive has intensified its propensity for breach of basic rights. The legislature has become a rubber stamp of executive needs so much that most of the laws passed today bring with them one form of human rights violation or other. The consequence of these two causes is that the judiciary is left with very little room for manoeuvre. There is probably nothing new in those two causes.

4

Ghai, Y.P., The Role of Law in Africa: Reflections on the Limits of Constitutionalism, Bergen, 1990, p. 1; Kibwana, K. (ed.), Law and the Administration of Justice in Kenya, Nairobi, International Commission of Jurists (Kenya Section) Publication, 1992.

5 Nehru, B.K., Westem Democracy and the Third World, Third World Quarterly, 1 (2) (1979), pp. 53-70. Nwabueze, B.O., Judicialism in Commonwealth Africa, London, 1977.

7 Ncube, W., Constitutionalism and Human Rights: Challenges of Democracy, in: P. Nherere / M. d'Engelbronner-Kolff (eds.), 1993, pp. 1-22, Fn. 1. 
Other causes of judicial powerlessness have been suggested which, together with the ones mentioned above, have enormous consequences to the image of judicial practices in human rights enforcement. Mwaikusa ${ }^{8}$ has suggested, and I think correctly, that there has been judicial subserviency to the executive. Justice Mwalusanya ${ }^{10}$, on the other hand, observes that the judiciary, which liberal democratic practice entrusts with redressing the abuse of power, cannot itself be exonerated from similar abuse. In his own words: "The judiciary is not spared of condemnation of abusing power at least by omission." He identifies six different ways in which judicial abuse of power has come about. These are: the failure to use the purposive and generous construction of the constitution, failure to deliver justice at the expense of law, delay of cases, abdication of adjudicative role on grounds of non justiciability, failure to use the power of judicial review (by means of prerogative orders) effectively and failure to bring domestic law in harmony with innovations in international human rights norms. These cannot be dismissed as simple or meaningless observations. Such observations made from within the judiciary itself express an acknowledgment, already known among some members of the general public, that the judiciary is no longer an effective means of redressing massive human rights violations experienced in every day life. These revelations bring into question the legitimacy of the judiciary as protector of human rights. The judiciary has exposed its powerlessness at the hands of both the executive and legislature.

In turn, members of the general public have become aware that present mechanisms of human rights enforcement are eliticist in both their character and enforcement. It is partly for that reason that some members of the public do not consider it appropriate to channel their grievances through ordinary courts. They prefer to do it elsewhere and through other means. Examples of such approaches are not very hard to find. Where these trends and tendencies do occur they are not necessarily due to criminal intention or ignorance of the respective rights and enforcement mechanisms but due to deliberate choices of which ways to proceed.

Deficiencies in judicial enforcement of human rights, otherwise labelled as judicial powerlessness, its causes and consequences lead to one conclusion. That is that the judiciary had an opportunity to safeguard human rights and that opportunity was wasted, partly for

Mwaikusa, J.T., Government Powers and Human Rights in Africa: Some Observations from Tanzanian Experience, Lesotho Law Journal, 1991, pp. 75-105.

Corder, H., Crowbars and Cobwebs: Executive Autocracy and the Law in South Africa, South African Journal of Human Rights, 5 (1) (1989), pp. 1-25.

10

Mwalusanya, J.L., Checking the Abuse of Power in a Democracy, Paper presented to a Conference on Constitutionalism and the Legal System in a Democracy, Arusha (Tanzania), 28-29th March 1995; Mwalusanya, J.L., Judgement in Chumchua Marwa v. Officer in charge Musoma Prison \& Attorney General, High Court of Tanzania (Mwanza) miscellaneous criminal cause no. 2 of 1988 (unreported). 
reasons outside its and partly for reasons caused by itself. There is every indication that the lost opportunity may be very difficult to regain. It is for that reason that thinking and discussing about complementary human rights enforcement mechanisms is a challenge worthy taking seriously and as early as possible.

It is beyond dispute that the executive in many countries continues to violate all categories of human rights and does not take judicial decisions seriously. Parliaments, on their part, continue to pass laws which not only impinge on individual and group rights but which also restrict judicial intervention. There is no indication to suggest that these trends are likely to subside. These trends and tendencies call for a reconsideration as to by which means all categories of human rights can be best protected in the light of the failures experienced within the conventional means. Some efforts are already being attempted to which we now turn.

\section{Enforcement of Social Justice: Some attempted Reforms}

Earlier it was observed that deficiencies in the enforcement of all categories of human rights is a phenomenon widely spread in both Common Law and Roman-Dutch jurisdictions throughout sub-saharan Africa. ${ }^{11}$ Whereas in some countries a discussion of these inadequacies is still avoided, in others, the discussion is restricted not only within professional circles but limited to senior officials only. Yet, in other countries, the weaknesses have not only been admitted, they have also been openly discussed and some reformative measures introduced. It cannot be said to have been easy but some efforts were made all the same. The introduction of public interest litigation (PIL) in the United States of America and social action litigation (SAL) in India are examples of mechanisms for the provision of relief to poor litigants and also remedying human rights violations committed to cross sections of people which would otherwise have passed without action. ${ }^{12}$ This may not be an appropriate occasion to review what the two reforms actually entail but it is worthy noting that the two were a result of acceptance of the fact that conventional human rights enforcement mechanisms were inadequate and that something positive and different had to be done. The two initiatives may be different but they have some similarities, too. Relevant here is that they were both initiated from within the respective legal systems.

Bukurura, S.H., Judiciary and Good Govemance in Contemporary Tanzania: Problems and Prospects, Bergen, 1995, pp. 3, 16.

12

Bhagwati, P.N., Judicial Activism and Public Interest Litigation, Columbian Journal of Transnational Law, 23 (1985), pp. 561-577. 
It has been noted that PIL in USA has declined because of it reliance on financial contributions which could not be sustained. ${ }^{13}$ Indian social action litigation, which was equally viewed with scepticism by some critics, on the other hand, has been getting stronger and stronger. Enthusiasm for it has been maintained because the senior judges who started it have managed to sustain the relentless vigour with which SAL was introduced. The initiators were public-spirited and also belonged to the highest court of the land - the Supreme Court. SAL has brought enormous achievements in the enforcement of social justice in India. ${ }^{14}$ Scepticism remains, but some members of the judiciary have learnt and the lessons have helped them to get out of the closed and identify with the sufferings of the poor masses, in the words of Upendra Baxi, suffering has been taken seriously by the judiciary. ${ }^{15}$ These Indian legal developments are well-known around Africa ${ }^{16}$, yet there is no indication that the mechanisms might be emulated by the judiciaries in the sub-region.

As much as conventional means of enforcing human rights have been found wanting by some sections within the legal systems of India and USA, so have government servants, who continue to inf ringe upon human rights with impunity. Members of the general public, on the other hand, have also been forced to look elsewhere in cases of perceived injustices and violations of rights. The executive with the help of parliament thinks it is appropriate to bypass ordinary courts in favour of administrative tribunals.

Conventional mechanisms have become so discouraging that in Tanzania, for example, a senior advocate once confided to a senior judge that:

"whenever people come to me with a civil dispute, I advise them to settle, however unfavourable the settlement to one of the parties, for it no longer is anybody's worth while to take disputes to court" ${ }^{17}$.

The above comment was made in relation to an ordinary civil suit. One imagines the sort of frustration concerning violation of other aspects of social justice in which the government or its officials are parties.

Cunningham, C.D., Public Interest Litigation in Indian Supreme Court: A Study in the Light of American Experience, Journal of Indian Law Institute, 29 (4) (1987), pp. 494-523.

Cottrell, S., Courts and Accountability: Public Interest Litigation in the Indian High Court, Third World Legal Studies, 1992, pp. 199-213.

Baxi, U., Taking Suffering Seriously: Social Action Litigation in the Supreme Court of India, in: $N$. Tiruchelvam / R. Coomaraswamy (eds.), The Role of the Judiciary in Plural Societies, London, 1987, pp. 32-60.

Meers, S., Litigating Fundamental Rights: Rights Litigation and Social Action Litigation in India: A Lesson for South Africa, South African Journal on Human Rights, 9 (3) (1993), pp. 358-372.

Mfalila, L.M.S., Administration of Justice in Tanzania: Delays in the Disposal of Cases, Judicial Bulletin, Journal of Judges and Magistrates Association (Tanzania), 1 (1989), pp. 13-18; for the situation in South Africa see Kahn, E., op. cit. (note 4). 
Some sections of the public have resorted to various forms of self-help, including mob justice, to enforce their right to life and protection of lawfully acquired property, where they felt that both the police and courts could not be relied on for protection. There has been an increase in vigilante action and other varieties of self-help mechanisms of law enforcement, be it in developed or developing countries. ${ }^{18}$ The emergence of the People Against Gangsterism and Drugs (PAGAD) in South Africa and mob justice, popularly known as mbayiyani-sm in Szaziland, are the recent examples. These activities partly suggest that the general public is getting frustrated with the inadequacies and, therefore, willing to bypass or withdraw from enforcing their rights through conventional means.

One of the lessons from the above discussion is that there are many kinds of social injustices being committed to masses of the people, especially the poor, and that existing mechanisms for redressing these injustices are both weak and inadequate. Some farsighted and pragmatic sections within the judiciary have already taken note of this and attempt, within their mandate, to alleviate the situation. There are only a few who have responded positively to the challenge and they have not found it easy. Indications are that the majority of justices are unwilling to face the challenge and are even sceptical of attempts made by their colleagues. It is from all the above that the problem has to be identified and broadly discussed if the current justice system is not to lose its significance.

\section{PAHURIE: A Research Agenda}

Concepts of justice in general and civil and political rights in particular are associated with and emanate from liberal democratic practices. It is from the sources of the rights that the limitations for their enforcement also have to be found. ${ }^{19}$ There is little doubt that the executive is entrenched and bound to intensify its abuse of power and encroachment of human rights. ${ }^{20}$ The failure of the legislature to keep the executive exercise of power in check is no longer a matter of debate. Judicial powerlessness in effective control of human rights infringements is now becoming apparent. What are the available methods that can be taken up for redressing public wrongs? This question needs to be thought about seriously and discussed publicly.

See Bukurura, S.H., The Maintenance of Order in Rural Tanzania: The Case of Sungusungu, Journal of Legal Pluralism and Unof ficial Law, 34 (1994), pp. 1-29. Workshop on Fundamental Rights and Freedoms and Public Order in Tanzania, 3rd-7th April 1995.

See Baxi, U., The Crisis of the Indian Legal System, New Delhi, 1982. 
Most of the current problems of human rights enforcement are a result of the fact that the rights in question have been defined elsewhere and have to be generally enforced without regard to the specific priority needs of the bearers of these rights. It is high time that the bearers of those rights have to be fully involved not only in identifying which rights they consider to be a priority, but also by showing the ways in which those rights are mostly infringed upon. It is the people themselves, therefore, who are capable of ultimately suggesting the potential means of minimising violations and the mechanisms for enforcement. In other words, the general public at all levels has to be involved not only in identifying the problem, but by also suggesting possible solutions. For want of a better term the suggested approach could be called "participatory human rights enforcement" (PAHURIE).

The social, political and constitutional basis for this mechanism may not be hard to find. The people, broadly defined, have always been said to be the source of all political power. It is for that reason that Abraham Lincoln's phrase "government of the people by the people for the people" is always quoted. The people are expected to be the ultimate beneficiaries of all political and legal action. Constitutions of different countries often start with preambles which recognize the sovereignty of the people. These constitutions, however, end up making little provisions for the realization of the people's political and social needs. Time has come to recognize the people's potential and, therefore, work towards its full empowerment.

On their part, the people, especially the poor, have already started working for their own benefit, be it economically of legally, in total disregard of the system they have found both exploitative and uncaring. They have already taken what is due to them. Brown quotes a writer in a popular law journal saying that:

"the doctrine of vigilance ... is based upon the theory that the people have a right to uphold perpetual vigil over their institutions and to correct, where necessary, abuses and corruption which threaten the security of their lives and property" ${ }^{21}$.

There is a need to change our attitudes in regard to what the people say and do. If we do learn, we will find out that what most of us might have wrongly thought illegitimate or illegal was and still is very legitimate in the eyes of the frustrated general public.

The people's potential needs to be both acknowledged and captured. In order to do the above there is need for inter-disciplinary research with encompasses not only lawyers, sociologists, anthropologists, political scientists but also the very people for whom social justice is intended.

21

Brown, R.M., Strain of Violence: Historical Studies in American Violence and Vigilantism, London, 1975, pp. 152-153. 
of multipartyism in 1990, the mostly christianized non-Moslems support President Biyas RDPC party and oppose the UNCP of the Peul Bello Bouba Maigari. Furthermore, the Kirdi constitute a very heterogeneous group in itself divided by numerous conflicts.

\section{Human Rights in Sub-Saharan Africa: Towards Complementary Enforcement of Social Justice}

\section{By Sufian Hemed Bukurura}

The past and present decades are said to epitomize the era of good governance and transparency. It is in that context that constitutionalism, human rights and democracy are contemporary subjects of discussion all over the world. These concepts mean a lot to the organization of societies in general and legal systems in particular.

The current economic, political and social set-up of Sub-Saharan Africa does not seem to ensure that constitutionalism, human rights and democracy are readily available for the enjoyment of all people. The paper is a modest attempt in marking some signposts towards the exploration of alternative enforcement mechanisms, considering, inter alia, public interest litigation, social action litigation and participatory human rights enforcement.

\section{The Constitition of Paraguay of 1992 and its Predecessors}

\section{By Anja Schoeller-Schletter}

After decades of authoritarian rule, brought to an end in 1989 by the overthrow of General Alfredo Stroessner who dominated the country's politics since 1954, Paraguay is experiencing a process of transition from military dictatorship to democracy. A new constitution, passed in 1992, laid the legal foundation for a democratic government. As a reaction to the deficits of the preceding constitutions of 1967 and 1940, executive power was considerably restricted, the legislature was strengthened and the judiciary was subjected to fundamental reforms in order to guarantee its independence. Regardless of all changes in the normative system, tradition in terms of political practices and social structure turns out to be an impediment to the process of democratization.

The survey focuses on the solutions of the constitution of 1992 for the normative and political problems of the constitution of 1967: the extension of human rights protection; the abolition of the presidential authority to dissolve the Congress and the control of Congress 